\title{
Strategic lockdown and blessing variation - potential success keys against COVID-19
}

\author{
Koutilya Bhattacharjee', Suvajit Saha², Emili Banerjee ${ }^{3}$, Partha Ganguly ${ }^{4}$ \\ ${ }^{1}$ Assistant Professor, ${ }^{4}$ Project Fellow, Department of Zoology, Ramakrishna Mission Vivekananda Centenary College, \\ West Bengal, India, ${ }^{2}$ Doctoral Research Fellow, Department of Microbiology, University of Calcutta, Kolkata, India, \\ ${ }^{3}$ Clinical Geneticist, Mukherjee Fertility Centre, West Bengal, India
}

A B S T R A C T

Background: COVID-19, a respiratory illness, has become a pandemic originating from the Wuhan city of China. Earlier, similar diseases like Severe Acute Respiratory Syndrome and Middle East Respiratory Syndrome had caused mass mortality in different parts of the globe. Therefore, a similar new disease was of great concern for the humankind. However, it is observed that COVID-19 has a differential rate disease prevalence and mortality among the countries. Aims and Objective: This disease has already affected 2.4 million people globally, leading to healthcare disasters, financial meltdowns due to worldwide lockdowns. Our objective was to evaluate the effect of lockdown in India and to characterize the functional implications of genetic variations of SARS-CoV-2 (the causative virus). Materials and Methods: Epidemiological data for COVID-19 was taken from WHO and other national or international bodies to evaluate the prevalence of the disease in different countries. A statistical modeling was done to estimate the probable number of COVID-19 affected persons with or without lockdown. Bioinformatic analyses were done to identify mutational variations of SARS-CoV-2 and their functional implications. Results: Statistical modeling predicted that number of COVID-19 case could be much higher without lockdown in countries. Countries with malaria and dengue prevalence are less affected by COVID-19. Bioinformatic analyses revealed presence of an Indian SARS-CoV-2 SP1 variant with lesser capability of human receptor binding. Conclusion: Lockdown and deliberate testing has played key important role in prevention of disease transmission. Indian variant of SARS-CoV-2 with less affinity towards human receptor may have a role for lesser virulence.

Key words: COVID-19; SARS-CoV-2; Missense mutation; Domain domain interaction; India

\section{Access this article online}

Website:

http://nepjol.info/index.php/AJMS DOI: 10.3126/ajms.v11i4.26464

E-ISSN: 2091-0576

P-ISSN: $2467-9100$

Copyright (c) 2020 Asian Journal of Medical Sciences

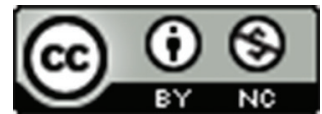

This work is licensed under a Creative Commons Attribution-NonCommercial 4.0 International License.

\section{INTRODUCTION}

Coronavirus is a family of positive strand RNA virus that causes flu like respiratory illnesses such us MERS (Middle East Respiratory Syndrome) and SARS (Severe Acute Respiratory Syndrome) and is sourced from animals with a zoonotic capability. ${ }^{1}$ The ICTV (International Committee on Taxonomy of Virus) named them such, because the virion particles typically possess peplomers or spikes of petal or club shaped surface projections which under electron microscope give an impression of Solar Corona. ${ }^{2}$ Apart from the six previously described human infective Coronavirus like HKU1, HCoV-NL63, HCoVOC43, HCoV-229E, SARS-CoV and MERS-CoV, 3 a new group member has started drawing global attention from December, 2019 which causes acute respiratory illness and has been named as SARS-CoV-2 by ICTV on 11 February, 2020 and the disease caused by it as COVID-19 by ICD. ${ }^{4}$ During the end of 2019, some people from Wuhan city of China were reported to have pneumonia attack and the causative agent was identified to be a novel betacoronavirus named as $\mathrm{nCoV}-19$, with $79.6 \%$ genomic sequence similarity to that of SARS-CoVV. ${ }^{5,6}$ As per the same report, infected patients typically had clinical features like fever,

Address for Correspondence:

Dr. Koutilya Bhattacharjee, Assistant Professor, Department of Zoology, Ramakrishna Mission Vivekananda Centenary College,

Punyananda Sarani, P.O- Rahara, Khardah, District - 24PGS (N), West Bengal, India. PIN - 700118. Mobile: +91-9831514055

E-mail: koutilya@rkmvccrahara.org 
dry cough, breathing difficulties and pneumonia leading to death in extreme cases. Infection spread at geometric rate and soon thousands got affected within weeks. ${ }^{5}$ Since then, a very rapid increase in patient count occurred throughout the globe.

Disease chronology was as follows - first case was reported in $31^{\text {st }}$ December, $2019{ }^{6}$ from Wuhan city, China which increased to a value of 44 patients within 3 days in the same place. ${ }^{7}$ In a month from the first report of COVID-19, on 30 $30^{\text {th }}$ January, 2020, the cases increased to a number of 7734 from China only and 90 cases from rest of the world including India, Sri Lanka, Nepal, Thailand, Taiwan, Japan, Singapore, Cambodia, Malaysia, United Arab Emirates, Republic of Korea, The Philippines, Canada, United States of America, Vietnam, Australia, Finland, France and Germany. Fatality was 170 out of these 7824 patients, i.e., nearly $2.2 \% .{ }^{8}$ Since then disease spreading took a geometric rate and within days global count of COVID-19 patients reached figure of hundred thousand. As of April 21, 2020, total count of COVID-19 patients in all affected countries is more than 2.3 million with a death toll of 162956 and thus fatality rate of $6.79 \% .{ }^{9}$ As per World Health Organization (WHO, Geneva, Switzerland), co-morbid effects are much more damaging to the COVID-19 patients having history of cardiovascular diseases, hypertension, diabetes, renal problems, respiratory diseases, lung diseases, etc. ${ }^{10}$

COVID-19 was declared as Public Health Emergency of International Concern (PHEIC) ${ }^{11}$ with primarily flu like symptoms leading to pneumonia and Acute Respiratory Distress Syndrome (ARDS) as per WHO guideline, while treatment was symptom based without any established pharmacoligal intervention. ${ }^{10}$ Indian Council of Medical Research (ICMR) initially recommended use of anti HIV drugs Lopinavir and Ritonavir in extreme cases ${ }^{12}$ however later in a revised statement ICMR recommended use of hydroxychloroquine as prophylactic measure. ${ }^{13}$ Hydroxychloroquine is widely used anti-malarial drug with known mechanism of actions. ${ }^{14}$ Use of anti-malarial drug for treatment of viral disease was definitely a fact for further cultivation. The present study was undertaken to find the possible causes of differential prevalence, mortality and recovery rate of COVID-19 in different part of the globe.

\section{MATERIALS AND METHODS}

\section{Comparison of disease distribution}

Global prevalence of COVID-19 was compared with that of malaria, since, the malarial drug was recommended as prophylactic measure. The comparison also included prevalence study of dengue, caused by another positive stranded RNA virus of Flaviviridae family. Recent prevalence map of COVID-19, malaria and dengue were taken from WHO and European CDC. ${ }^{15-17}$ Countries with higher prevalence of COVID-19 were checked for prevalence of dengue and malaria.

Epidemiological datasets of different COVID-19 affected countries were summarized to calculate country specific death and recovery rate. Data was taken from WHO situation updates and/or country specific government statistics.

\section{Statistical model to estimate effect of lockdown on COVID19 infections}

Confirmed COVID19 infection cases as reported by WHO and European Centre for Disease Prevention and Control (Sweden) were analyzed with regression statistical model using Origin software (version 8.5). Number of days since the $100^{\text {th }}$ confirmed cases reached has been taken into consideration for the statistical analysis. Best fitted nonlinear regression model has been employed to derive predictive curve equations and to study the changes in the equations after lockdown has been enforced.

Exponential growth and logistic sigmoid functions have been used by considering ' $y$ axis' as the dependent variable i.e., cumulative number of positive cases and ' $x$ axis as the independent variable i.e number days since the $100^{\text {th }}$ confirmed cases reached. For easy understanding, the date when 100 confirmed cases reached considered in the model as Day 1 and so forth.

The study has been conducted with the five leading countries with highest COVID19 diseases burden (viz. Italy, France, Germany, USA, UK) and with India which is approaching to the infection category Stage-03).

Analysis of Genomic variations of reported SARSCoV-2 sequences

We further searched for genetic variations among SARSCoV-2 variants spreading in different countries to assess any effective mutational variant. Available whole genomic RNA sequences of SARS-CoV-2 reported to public database NCBI were analyzed for their comparative base composition through Multiple Sequence Alignment (MSA) using CLUSTAL W ${ }^{18}$ and MEGA version $7 .{ }^{19}$

In Silico protein secondary structure prediction analysis Predictive changes in secondary structure of viral proteins due to nucleotide variations were analyzed through Chou and Fasman Secondary Structure Prediction Server (CFSSP Server - biox.ml/cff ${ }^{20}$ and PSIPRED. ${ }^{21}$ 
In Silico protein domain-domain interaction prediction analysis

Prediction of binding affinity and dissociation constant values of SARS-CoV-2 protein variants with corresponding human receptor proteins were analyzed using In SiLico protein AffiNity preDictor (ISLAND) ${ }^{22}$ tool. Domain lengths were selected as per Lan et. al., 2020. ${ }^{23}$

\section{RESULTS}

COVID-19 is less prevalent in countries with higher malaria and dengue

When global prevalence maps of COVID-19, malaria and dengue were comparatively studied, we observed that except Iran, rest of the COVID-19 affected top 10 countries (as per WHO) were Malaria free since 2017 and all of those top 10 countries are with extreme low risk of Dengue (Figure 1).

We presume that populations battling with community infections like dengue and malaria have evolved to produce faster and stronger immune response, which is making them lesser susceptible to COVID-19. Further, both Malaria and Dengue are mosquito-borne diseases. It has already been reported that mosquito saliva itself has notable immunomodulatory effects leading to higher innate immune response in humanized mice..$^{24,25}$ Therefore, continuous exposure to insect bites and insect components probably is sensitizing the immune response of people of these countries.

Prevention of COVID-19 spreading remains a challenge for our world. Countries like Republic of Korea and Germany went for mass screening of SARS-CoV-2, for instant identification of infected individuals and to start treating them in isolation. But, India prioritised symptoms based treatment with a national lockdown for six weeks. With this strategy, India, with a higher population density is successfully keeping the rate of new infection low (Table 1).

Only Italy and China among the most affected 10 countries by COVID-19 has lesser health care index than India yet India is successful in restricting the number of active cases of COVID-19 near about 20000 even after more than two months from first reported case. ${ }^{26}$ Therefore, enforcing social distancing through lockdown at right point of time was indeed a very good administrative decision for such a densely-populated so-called developing country.

Regression analysis of disease spreading with or without lockdown

For each country two regression models have been established. The first best fitted curve and respective equation was derived with the data of prior to lockdown has been enforced and the second one was deduced with all the data available till preparation of this manuscript. A distinct variation has been observed between the two statistical models across all the countries which has been studied (Table 2).

In Italy, France, Germany and UK, the infection growth curve was approaching exponentially before lockdown phase and became flattened after lockdown has been encountered and initiated to transform into sigmoid function at the present stage (Table 2). By the present model it has been detected that if the lockdown was not applied, the present cumulative number of COVID19 cases may reaches up to maximum 20 times more than the observed cases till 20 $0^{\text {th }}$ April, 2020. However in USA, where total lockdown has not been officially enforced, resulting the growth of infection rates are still increasing with exponential function.

According to our predictive value we have obtained that number of cases reduces $\sim 20$ times, $\sim 15$ times, $\sim$ 6times and $\sim 5$ times of observed cases in Italy, France, UK and Germany respectively. Interestingly lockdown has been implemented $1^{\text {st }}$ in Italy, $2^{\text {nd }}$ in France, $3^{\text {rd }}$ in UK and $4^{\text {th }}$ in Germany. Thus it is evidentially postulated that impact of lockdown is critically depended on the time from when it has been encountered.

\section{Mapping of Genetic variations}

Complete genome sequence of the virus was first published and submitted to GISAID (Accession no EPI_ISl_402124) in January 24, $2020^{5}$ with a greater than $90 \%$ sequence homology with that of Chinese bats (Rhinolophus affinis).

22 entries of SARS-CoV-2 genome from 13 countries were utilized for present analyses. The first reported genomic sequence from Wuhan, China (NCBI Id: NC_045512.2) is taken as the reference sequence for comparative genomic analyses. We found presence of only 32 single nucleotide variations and only one trinucleotide deletion among those 22 entries from different part of the globe (Supplementary material).

Out of these 32 variants 27 were present in the first large protein called polyprotein of the virus, encoded by "ORF1ab" gene. Characterizations of these 27 variations revealed that among them 2 are missense, 9 are neutral and 16 are silent in nature.

There are 3 missense variations and one trinucleotide deletion found in the surface glycoprotein gene called the spike protein (SP1), that the virus uses to enter into host cell. The missense variations cause a change in 221, 408 


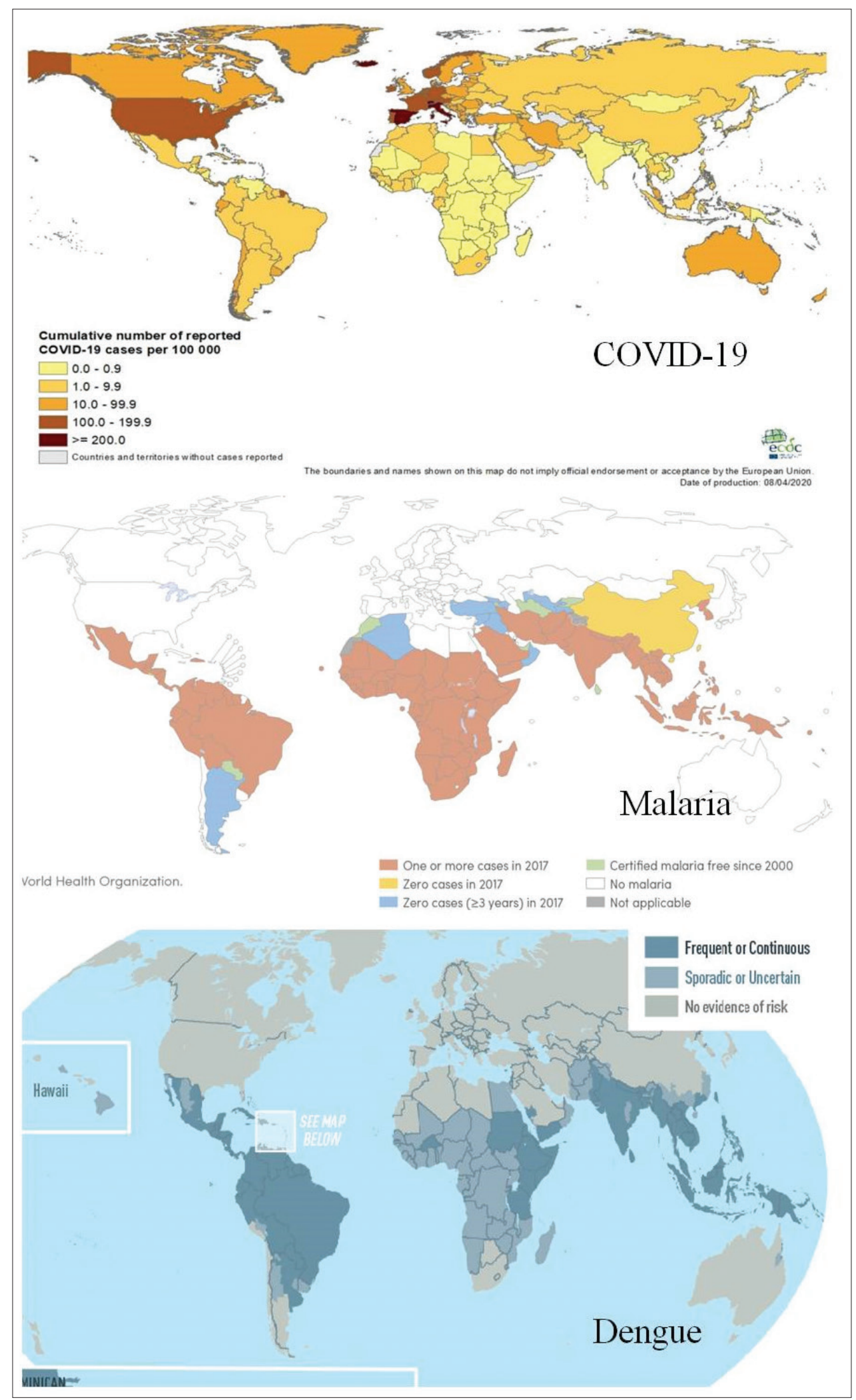

Figure 1: Comparative global distribution of COVID-19 with that of Malaria. Countries that are most affected by COVID-19 as per WHO are devoid of Malaria since 2017 or before except Iran. Map credit for COVID-19 goes to Europian Union Centre for Disease Control (ECDC) and map credit for Malaria goes to World Health Organization (WHO)

and 797 numbered amino acids of SP1 glycoprotein. The Arg408 to Ile408 variation was predicted to be capable of altering the local secondary structure of SP1. Interestingly, one entry (NCBI Id: MT_012098.1, Kerala, India) carried 


\begin{tabular}{|c|c|c|c|c|c|c|c|c|c|}
\hline \multirow{2}{*}{$\begin{array}{l}\text { SOURSE } \\
\text { Nation }\end{array}$} & \multirow{2}{*}{$\begin{array}{c}\text { WHO } \\
\begin{array}{c}\text { Confirmed } \\
\text { cases }\end{array}\end{array}$} & \multirow{2}{*}{$\begin{array}{c}\text { WHO } \\
\text { Cases } \\
\text { per 1M } \\
\text { people }\end{array}$} & \multirow{2}{*}{$\begin{array}{c}\text { WHO } \\
\text { Recovered }\end{array}$} & \multirow{2}{*}{$\begin{array}{l}\text { WHO } \\
\text { Deaths }\end{array}$} & \multirow[t]{2}{*}{$\begin{array}{l}\text { Mortality } \\
(\%)\end{array}$} & \multicolumn{4}{|c|}{$\begin{array}{c}\text { WHO, Country CDCs/ Ministry of Health; situation } \\
\text { update }\end{array}$} \\
\hline & & & & & & $\begin{array}{l}\text { Infection } \\
\text { I day at } \\
\text { exponential } \\
\text { phase }\end{array}$ & $\begin{array}{l}\text { recovery } \\
\%\end{array}$ & $\begin{array}{l}\text { Popln } \\
\text { density } \\
\text { /sq km }\end{array}$ & $\begin{array}{c}\text { Health Index } \\
\text { (https://www. } \\
\text { numbeo.com/ } \\
\text { health-care) }\end{array}$ \\
\hline World & 2397216 & 307.33 & 97,636 & 162956 & 6.79 & $\ldots$ & 7.60 & 14.7 & NA \\
\hline \multicolumn{10}{|c|}{ Top 10 affected countries } \\
\hline USA & 751273 & 2,479 & 83,203 & 35,884 & 4.77 & 8553.37 & 11.07 & 35.3 & 69.27 \\
\hline Spain & 200210 & 4,457 & 85,915 & 20,852 & 10.41 & 3894.9 & 42.91 & 92.4 & 78.88 \\
\hline Italy & 181228 & 3,043 & 51,600 & 24,114 & 13.30 & 2967.5 & 28.47 & 200.6 & 66.59 \\
\hline Germany & 143457 & 1,779 & 99,400 & 4598 & 3.20 & 2617.542857 & 69.28 & 234.6 & 73.32 \\
\hline $\begin{array}{l}\text { United } \\
\text { Kingdom }\end{array}$ & 124747 & 1,966 & 371 & 16509 & 13.23 & 1393.566667 & 0.03 & 279.4 & 74.46 \\
\hline France & 113,513 & 2,421 & 39,181 & 20233 & 17.82 & 1933.06 & 34.51 & 118.3 & 79.99 \\
\hline Turkey & 90980 & 1,133 & 14,918 & 501 & 0.55 & 1402 & 16.39 & 107.6 & 69.8 \\
\hline China & 84,250 & 58 & 77,151 & 4642 & 5.50 & 2471.93 & 91.57 & 148.2 & 64.48 \\
\hline Iran & 83,505 & 1,024 & 63,113 & 5209 & 6.23 & 1426.74 & 75.57 & 50.9 & 51.7 \\
\hline $\begin{array}{l}\text { Russian } \\
\text { Federation }\end{array}$ & 52763 & 2,438 & 6,415 & 456 & 3.25 & 703.06 & 31.30 & 209.6 & 72.44 \\
\hline \multicolumn{10}{|c|}{ Details of South East Asian Countries (According to WHO) } \\
\hline India & 18601 & 15 & 3,976 & 590 & 3.17 & 172.31 & 21.37 & 419.7 & 67.13 \\
\hline Indonesia & 6760 & 27 & 913 & 590 & 8.72 & 99.6 & 13.5 & 143.6 & 60.48 \\
\hline Bangladesh & 2948 & 23 & 92 & 101 & 3.42 & $\ldots$ & 3.12 & 1116 & 42.8 \\
\hline Thailand & 2811 & 40 & 2,352 & 48 & 1.70 & 103.52 & 83.67 & 136 & 77.95 \\
\hline Sri Lanka & 304 & 15 & 105 & 7 & 2.30 & 13.54 & 34.53 & 326.3 & 72.53 \\
\hline Maynmar* & 119 & 0.367 & 0 & 5 & 4.20 & $\ldots$ & 0 & 83 & 48.38 \\
\hline Maldives* & 67 & 159 & 16 & 0 & 0 & $\ldots$ & 23.88 & 1801.8 & 40.6 \\
\hline $\mathrm{Nepal}^{*}$ & 31 & 2 & 7 & 0 & 0 & $\ldots$ & 22.58 & 197.9 & 56.88 \\
\hline Bhutan* & 6 & 8 & 2 & 0 & 0 & $\ldots$ & 33.33 & 20 & 62.64 \\
\hline Timor-Leste* & 23 & 17 & 0 & 0 & 0 & $\ldots$ & 0 & 89 & 54.58 \\
\hline
\end{tabular}

the deletion as well as this $\operatorname{Arg}(\mathrm{R})$ to Ile (I) missense mutation.

In Silico functional implication prediction due to amino acid change

According to Lan et. al. 2020, ${ }^{23}$ SARS-CoV-2 SP1 protein interacts with human angiotensin-converting enzyme 2 (ACE2) through a domain from Thr333 to Gly526. Arg408 lies in the $\alpha 2$ domain of the SP1 protein with a complete helical secondary structure. ${ }^{23}$ This Arg to Ile missense variation of SP1 was changing the $408^{\text {th }}$ amino acid of its receptor binding domain (RBD), thus creating a probability, to alter the SP1-ACE2 domain-domain interaction.

The helical $\alpha 2$ domain was composed of the hexapeptide GDEVRQ that was converted in the Indian variant as GDEVIQ which converted the last two amino acids of the hexapeptide in strand type secondary structure (Figure 2) resulting in a helix-strand combination. Such change in RBD could possibly change the binding affinity of SP1 with ACE2.

Amino acid sequences of human ACE2 domain and SARS-CoV-2 SP1 binding domain were selected as per Lan et. al., $2020 .{ }^{21}$ Ile 408 variant has a $\Delta \Delta G$ value of -10.79 and dissociation constant $\left(\mathrm{K}_{\mathrm{d}}\right)$ value of $1.21 \times 10^{-08} \mathrm{~mol} / \mathrm{L}$, whereas variant $\operatorname{Arg} 408$ has a $\Delta \Delta G$ value of -10.82 and dissociation constant $\left(\mathrm{K}_{\mathrm{d}}\right)$ value of $1.15 \times 10^{-08} \mathrm{~mol} / \mathrm{L}$. Thus, Ile408 variant will have weaker SP1 - ACE2 domain-domain interaction.

Dissociation constant at the level $10^{-4} \mathrm{~mol} / \mathrm{L}$ is considered as weak interaction and at $10^{-10} \mathrm{~mol} / \mathrm{L}$ is considered as strong. As both the dissociation constant is at $10^{-8}$ $\mathrm{mol} / \mathrm{L}$ range, therefore interaction between SP1-ACE2 in moderate in nature. At such range, reduced binding affinity due to missense mutation might be playing a blessing role for the Indian patients with lesser virulence. 
Table 2: Best fitted curve with predictive regression equations. $Y$ is the function of $X$. Value of $y$ axis can be predicted with the respective equations for any value of $X$. Number of days should be adjusted from the date of Day 1 for effective prediction. All the statistical models are significant at 0.001 level

Without lockdown

INDIA, Day1: 16.03.2020

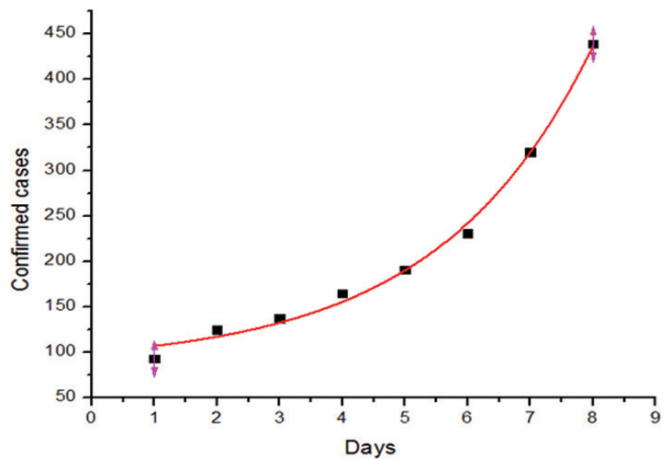

Exponential curve

\begin{tabular}{|c|c|c|c|c|}
\hline & A & $B$ & c & D \\
\hline 1 & Model & ExpGro1 & & \\
\hline 2 & Equation & $y=A 1^{\star} \exp (x t 1)$ & $+y_{0}$ & \\
\hline 3 & $\begin{array}{l}\text { Reduced Chi-S } \\
\text { qr }\end{array}$ & 98.41466 & & \\
\hline 4 & Adj. R-Square & 0.99264 & & \\
\hline 5 & & & Value & Standard Error \\
\hline 8 & C & yo & 86.76201 & 12.12429 \\
\hline 7 & C & A1 & 13.50455 & 4.7085 \\
\hline 8 & C & t1 & 2.45761 & 0.24892 \\
\hline
\end{tabular}

ITALY, Day 1: 24.02.2020

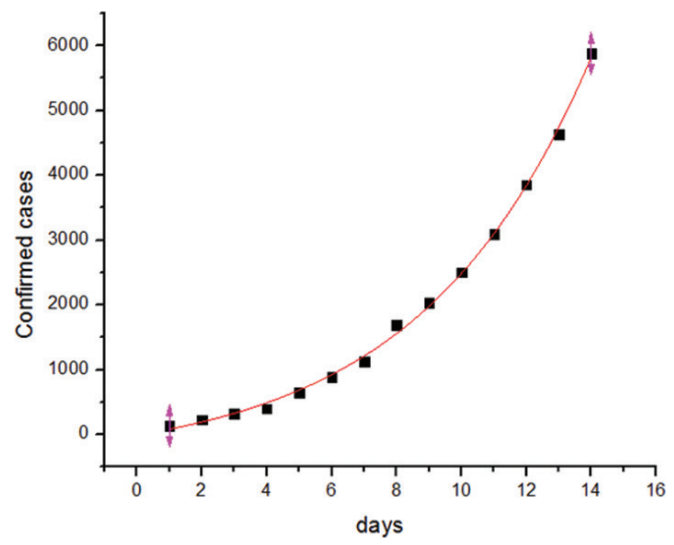

Exponential curve

\begin{tabular}{|c|c|c|c|c|}
\hline & A & B & c & D \\
\hline 1 & Model & ExpGro1 & & \\
\hline 2 & Equation & \multicolumn{2}{|c|}{$y=A 1^{\star} \exp (x t 1)+y 0$} & \\
\hline 3 & $\begin{array}{l}\text { Reduced Chi-S } \\
\text { qr }\end{array}$ & 5139.52347 & & \\
\hline 4 & Adj. R-Square & 0.99844 & & \\
\hline 5 & & & Value & Standard Error \\
\hline 6 & cases & yo & -451.03337 & 88.0941 \\
\hline 7 & cases & A1 & 439.45827 & 47.49343 \\
\hline 8 & cases & $\mathrm{t} 1$ & 5.26404 & 0.19847 \\
\hline
\end{tabular}

With lockdown

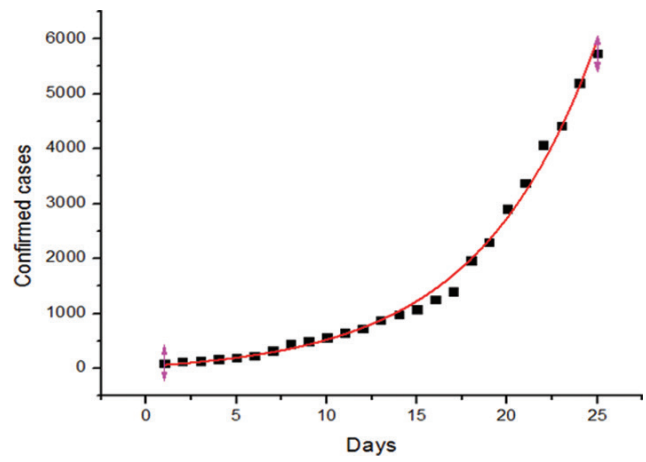

Exponential curve

\begin{tabular}{|c|c|c|c|c|}
\hline & A & B & c & D \\
\hline 1 & Model & ExpGro1 & & \\
\hline 2 & Equation & $y=A 1^{\star} \exp (x / t 1)$ & $+y 0$ & \\
\hline 3 & $\begin{array}{l}\text { Reduced Chi-S } \\
\text { qr }\end{array}$ & 18063.54556 & & \\
\hline 4 & Adj. R-Square & 0.99384 & & \\
\hline 5 & & & Value & Standard Error \\
\hline 8 & C & yo & -92.47303 & 71.66192 \\
\hline 7 & C & A1 & 133.10008 & 22.17147 \\
\hline 8 & c & t1 & 6.54077 & 0.28434 \\
\hline
\end{tabular}

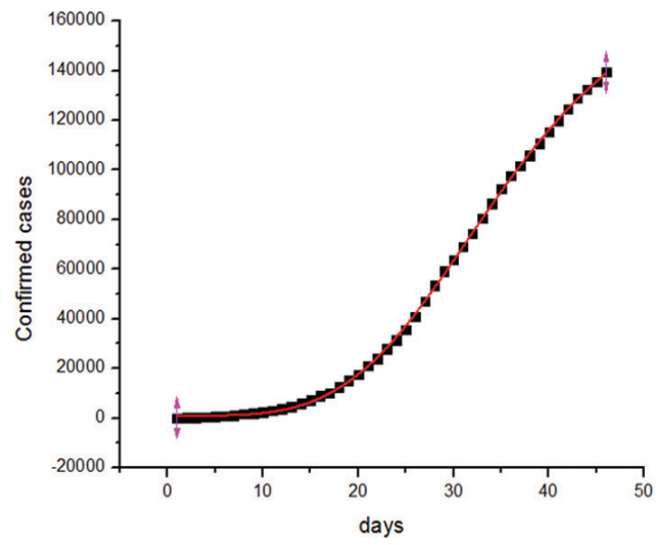

Sigmoid curve

\begin{tabular}{|c|c|c|c|c|}
\hline & A & B & c & D \\
\hline 1 & Model & Logistic & & \\
\hline 2 & Equation & $y=A 2+(A 1-A 2)$ & $v\left(1+(x / \times 0)^{n} p\right)$ & \\
\hline 3 & $\begin{array}{l}\text { Reduced Chi-S } \\
\mathrm{qr}\end{array}$ & 491518.84532 & & \\
\hline 4 & Adj. R-Square & 0.99979 & & \\
\hline 5 & & & Value & Standard Error \\
\hline$\theta$ & cases & A1 & 972.19362 & 203.49017 \\
\hline 7 & cases & A2 & 188300.28414 & 2342.92147 \\
\hline 8 & cases & xo & 35.61939 & 0.24247 \\
\hline 9 & cases & p & 4.02476 & 0.04994 \\
\hline 10 & cases & EC20 & 25.24047 & \\
\hline 11 & cases & EC50 & 35.61939 & \\
\hline 12 & cases & EC80 & 50.26612 & \\
\hline
\end{tabular}

(Contd...) 
Table 2: (Continued)

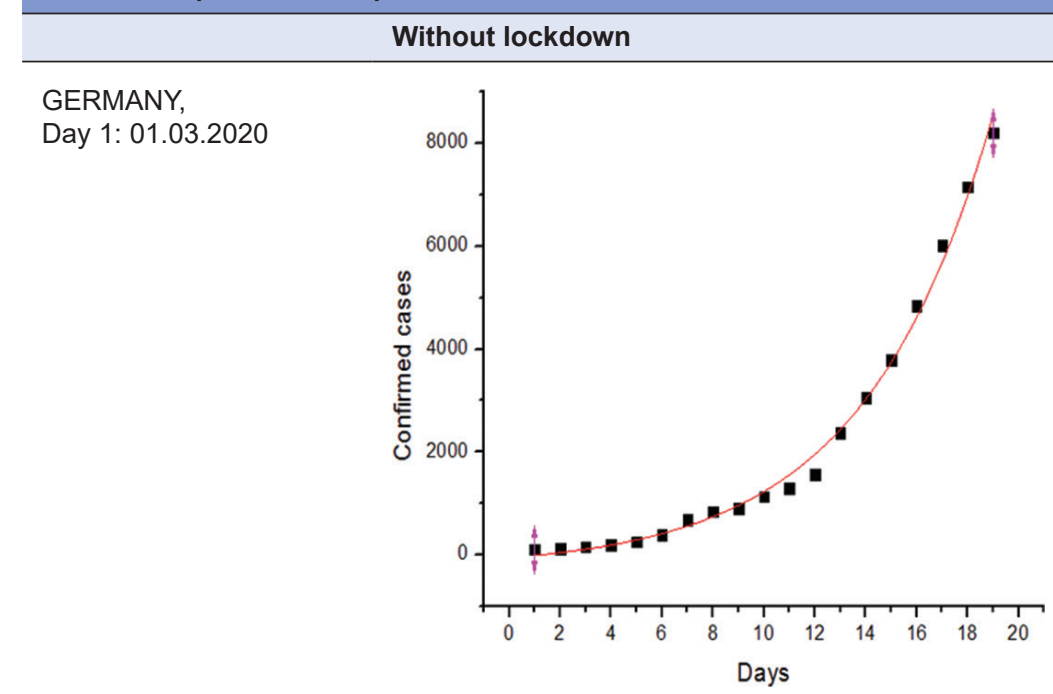

Exponential curve

\begin{tabular}{|c|c|c|c|c|}
\hline & A & B & c & D \\
\hline 1 & Model & ExpGro1 & & \\
\hline 2 & Equation & $y=A 1^{\star} \exp (x t 1)$ & $+\mathrm{y}_{0}$ & \\
\hline 3 & $\begin{array}{l}\text { Reduced Chi-S } \\
\text { qr }\end{array}$ & 37945.76247 & & \\
\hline 4 & Adj. R-Square & 0.99417 & & \\
\hline 5 & & & Value & Standard Error \\
\hline 8 & $\begin{array}{l}\text { Confirmed cas } \\
\text { es }\end{array}$ & yo & -262.3292 & 122.64414 \\
\hline 7 & $\begin{array}{l}\text { Confirmed cas } \\
\text { es }\end{array}$ & A1 & 207.98311 & 38.99789 \\
\hline 8 & $\begin{array}{l}\text { Confirmed cas } \\
\text { es }\end{array}$ & t1 & 5.0706 & 0.25118 \\
\hline
\end{tabular}

FRANCE, Day 1: 01.03.2020

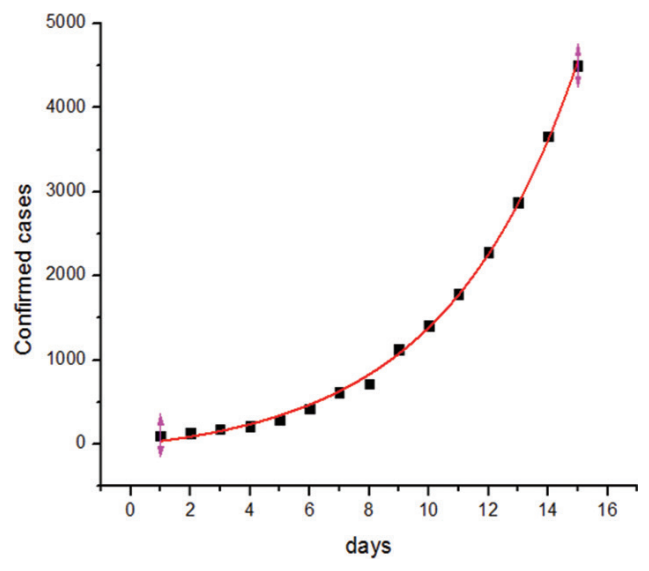

Exponential curve

\begin{tabular}{|c|c|c|c|c|}
\hline & A & B & C & D \\
\hline 1 & Model & ExpGro1 & & \\
\hline 2 & Equation & $y=A 1^{*} \exp (x t 1)$ & $+y 0$ & \\
\hline 3 & $\begin{array}{l}\text { Reduced Chi-S } \\
\text { qr }\end{array}$ & 2808.79511 & & \\
\hline 4 & Adj. R-Square & 0.99856 & & \\
\hline 5 & & & Value & Standard Error \\
\hline 8 & cases & yo & -178.54273 & 44.62938 \\
\hline 7 & cases & A1 & 171.38944 & 17.63486 \\
\hline 8 & cases & $\mathrm{t} 1$ & 4.52109 & 0.13582 \\
\hline
\end{tabular}

\section{With lockdown}

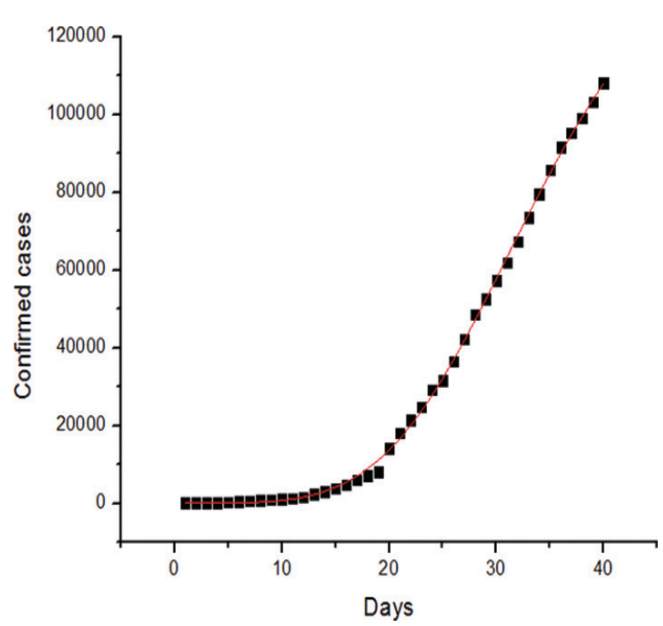

Sigmoidal curve

\begin{tabular}{|c|c|c|c|c|}
\hline & A & B & c & D \\
\hline 1 & Model & Logistic & & \\
\hline 2 & Equation & $y=A 2+(A 1-A 2)$ & $\left.(1+(x) \times 0)^{\wedge} p\right)$ & \\
\hline 3 & $\begin{array}{l}\text { Reduced Chi-S } \\
\text { qr }\end{array}$ & 973151.05354 & & \\
\hline 4 & Adj. R-Square & 0.99926 & & \\
\hline 5 & & & Value & Standard Error \\
\hline 8 & $\begin{array}{l}\text { Confirmed cas } \\
\text { es }\end{array}$ & A1 & 101.17067 & 284.98918 \\
\hline 7 & $\begin{array}{l}\text { Confirmed cas } \\
\text { es }\end{array}$ & A2 & 163045.43879 & 5449.39492 \\
\hline 8 & $\begin{array}{l}\text { Confirmed cas } \\
\text { es }\end{array}$ & $x_{0}$ & 34.34406 & 0.54139 \\
\hline 9 & $\begin{array}{l}\text { Confirmed cas } \\
\text { es }\end{array}$ & p & 4.42698 & 0.11348 \\
\hline
\end{tabular}

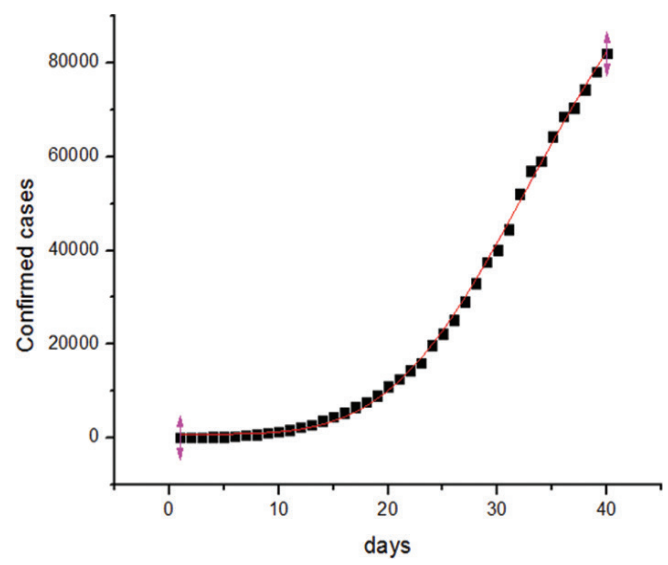

Sigmoid curve

\begin{tabular}{|c|c|c|c|c|}
\hline & A & B & c & D \\
\hline 1 & Model & Logistic & & \\
\hline 2 & Equation & $y=A 2+(A 1-A 2)$ & $\left(1+(x / \times 0)^{\wedge} p\right)$ & \\
\hline 3 & $\begin{array}{l}\text { Reduced Chi-S } \\
\text { qr }\end{array}$ & 903255.53539 & & \\
\hline 4 & Adj. R-Square & 0.99874 & & \\
\hline 5 & & & Value & Standard Error \\
\hline 8 & cases & A1 & 848.9368 & 273.13112 \\
\hline 7 & cases & A2 & 135576.73397 & 7198.70916 \\
\hline 8 & cases & xo & 36.25144 & 0.88686 \\
\hline 9 & cases & $p$ & 4.37439 & 0.14975 \\
\hline 10 & cases & EC20 & 26.40537 & \\
\hline 11 & cases & EC50 & 36.25144 & \\
\hline 12 & cases & EC80 & 49.76892 & \\
\hline
\end{tabular}

(Contd...) 
Table 2: (Continued)

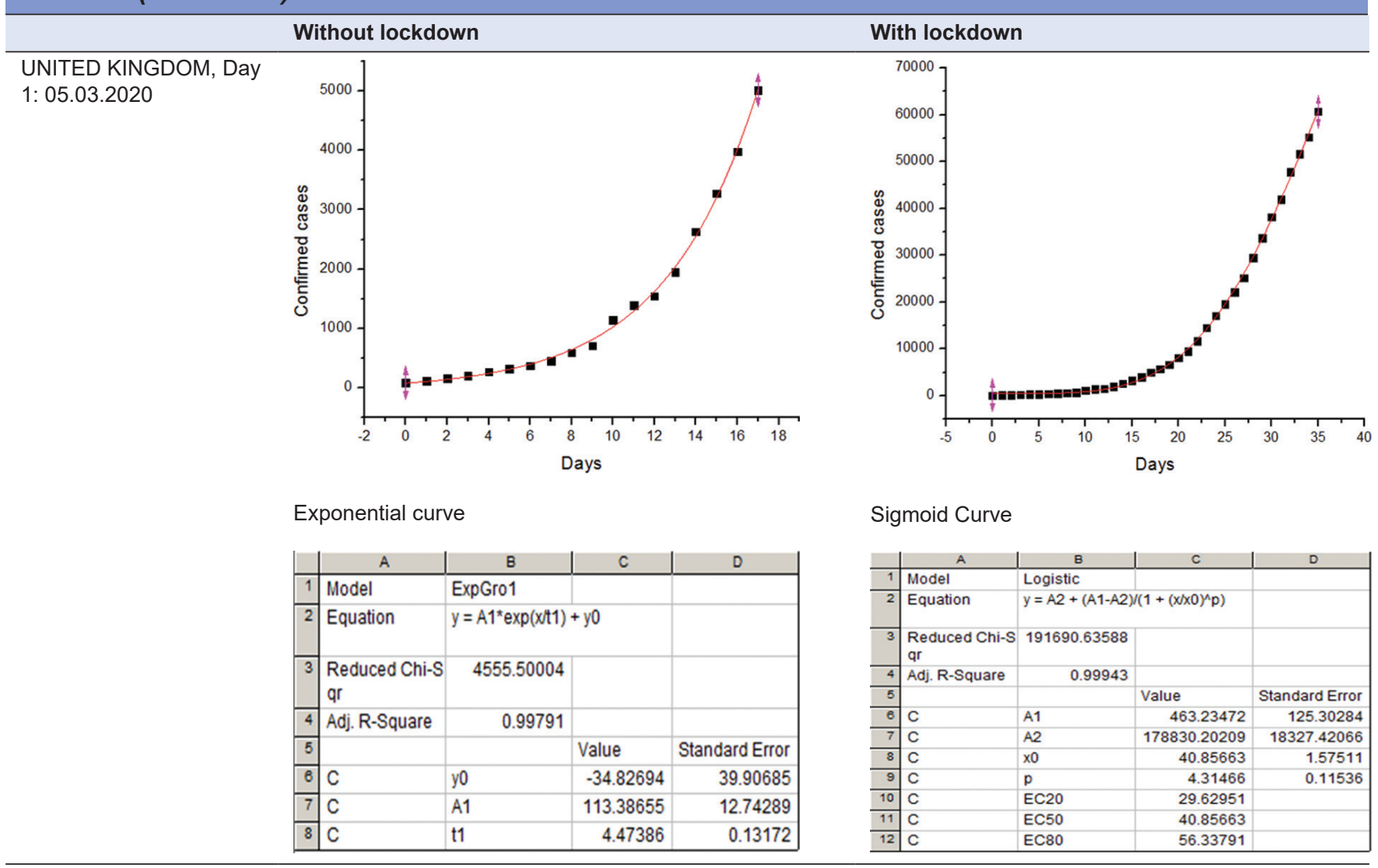

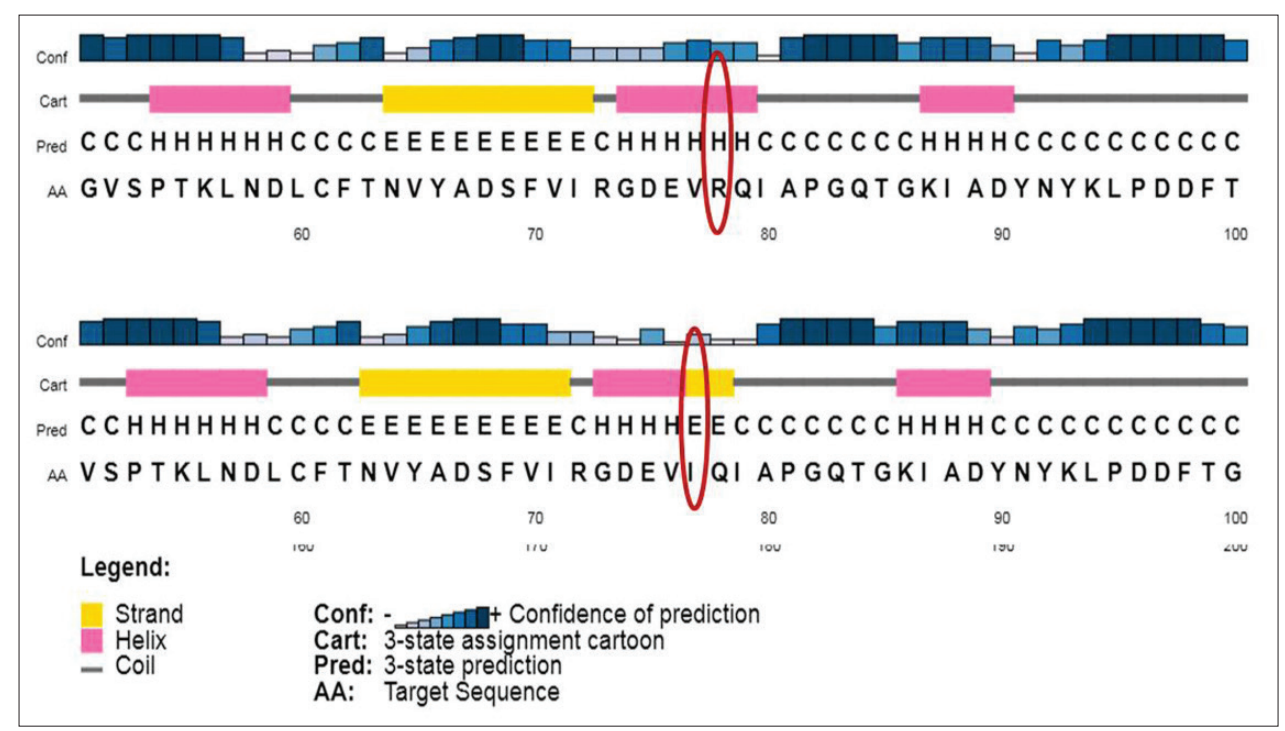

Figure 2: Comparison of secondary structure prediction through CFSSP Server - biox.ml/cf of the R to I missense variation on 408AA of SP1 protein of SARS-CoV-2. This missense altered the $\alpha 2$ motif of the Receptor Binding Domain of SP1. The complete helical structure of GDEVRQ was converted to helix-strand combination due to the change of GDEVIQ

\section{DISCUSSION}

The present anti-COVID-19 policy is to identify the infection hotspots in the country and dedicated screening of every individual present there through rapid and effective testing. This dual way approach has already given better results in limiting infection as can be seen from the situation of different countries like India as well as Republic of Korea and others. Higher prevalence of arbo-vector borne diseases like malaria and dengue may 
have sensitized population immunity in a more active state. Low but continuous exposure to pathogens of malaria and dengue might have been the cause of this greater active viral tolerance. Presence of single missense variation in the RBD of SP1 is reducing its affinity towards human ACE2 receptor. Other two missense variants are not within the RBD, hence Arg408 to Ile408 is the only functionally important change found in the viral protein. This variant was reported to be present in virus isolated from Kerala state of India, where the mortality due to COVID-19 is extremely low. Kerala has reported only 3 deaths out of 447 COVID-19 cases with a recovery rate of $72.48 \%$ till preparation of this manuscript as per Ministry of Health and Family Welfare, Government of India statistics on April 24, 2020. ${ }^{27}$ From an early evolutionary point of view, the viral genome is globally almost conserve and thus pharmacological intervention, discovered or invented, will also supposed to be globally effective cure.

Elaborate research is being carried throughout the globe on SARS-CoV-2 and COVID-19 for its prevention and prophylactic measure. We propose some specific aspects in this regard. Immunological profiling of lesser COVID-19 prevalent populations and simulation profiling of bat immune response probably hold the key success in fighting this disease. We know that this virus is originated from bat, but there is no report that bats are facing heavy mortality due to this infection. Let us hope for earliest possible invention or discovery of antiviral measurement against SARS-CoV-2 so that the human race can reaffirm their dominance on this planet.

\section{REFERENCES}

1. Details of Coronavirus. Available from: https://www.who.int/docs/ default-source/sri-lanka-documents/what-is-coronavirusenglish.pdf?sfvrsn=a6b21ac_2.

2. Taxonomy of Coronavirus. Available from: https://talk.ictvonline. org/ictv-reports/ictv_9 ${ }^{\text {th }}$ _report/positive-sense-rna-viruses2011/w/posrna_viruses/222/coronaviridae.

3. Rabi FA, Al Zoubi MS, Kasasbeh GA, Salameh DM and Al-Nasser AD. SARS-CoV-2 and Coronavirus Disease 2019: What We Know So Far. Pathogens 2020; 9: 231-244. https://doi.org/10.3390/pathogens9030231

4. Technical guidance of COVID-19 released by WHO. Available from: $\quad$ https://www.who.int/emergencies/diseases/novelcoronavirus-2019/technical-guidance/naming -the-coronavirusdisease-(covid-2019)-and-the-virus-that-causes-it.

5. Zhou P, Yang XL, Wang XG, Hu B, Zhang L, Zhang W, et al. A pneumonia outbreak associated with a new coronavirus of probable bat origin. Nature 2020; 579(7798): 270-273. https://doi.org/10.1038/s41586-020-2012-7

6. Du Toit A. Outbreak of a novel coronavirus. Nat Rev Microbiol 2020; 18: 123.

https://doi.org/10.1038/s41579-020-0332-0

7. Novel Coronavirus (2019-nCoV) Situation report - 1, WHO,
21 January 2020. Available from: https://www.who.int/docs/ default-source/coronaviruse/situation-reports/20200121-sitrep1-2019-ncov.pdf

8. Bassetti M, Vena A and Giacobbe DR. The Novel Chinese Coronavirus (2019- nCoV) Infections: challenges for fighting the storm. Eur J Clin Invest 2020; 50: e13209- e13212.

https://doi.org/10.1111/eci.13209

9. COVID-19 situation report - 92 by World Health Organization. Available from: https://www.who.int/docs/default-source/ coronaviruse/situation-reports/20200421-sitrep-92-covid-19. pdf?sfvrsn=38e6b06d_4.

10. Clinical management of severe acute respiratory infection (SARI) when COVID-19 disease is suspected. Interim guidance by World Health Organization. 13 March 2020. Available from: https://www.who.int/publications-detail/clinical-managementof-severe-acute-respiratory-infection-when-novel-coronavirus(ncov)-infection-is-suspected

11. World Health Organization. Statement on the second meeting of the International Health Regulations (2005) Emergency Committee regarding the outbreak of novel coronavirus (2019-nCoV). Geneva: WHO; 2020. Available from: https:// www.who.int/news-room/detail/30-01-2020-statement-onthe-second-meeting-of-the-international-health-regulations(2005)-emergency-committee-regarding-the-outbreak-of-novelcoronavirus-(2019-ncov)

12. Coronavirus: HIV medications can be utilized in extreme cases, says ICMR. Available from: https://microbiozindia.com/healthnews/coronavirus-hiv-medications-can-be-utilized-in-extremecases-says-icmr/.

13. Advisory on use of Hydroxy-chloroquine as prophylaxis for SARS-CoV-2 infection. Available at: https://www.mohfw.gov.in/ pdf/Advisory on the use of Hydroxy chloro quinasprophylaxis for SARSCoV2 infection.pdf.

14. Ben-Zvi I, Kivity S, Langevitz $P$ and Shoenfeld $Y$. Hydroxychloroquine: from malaria to autoimmunity, Clin Rev Allergy Immunol 2012; 42(2): 145-153. https://doi.org/10.1007/s12016-010-8243-x

15. Global map of Covid-19, situation update, European Centre for Disease Prevention and Control. Available from: https://www. ecdc.europa.eu/en/geographical-distribution-2019-ncov-cases.

16. Dengue around the world. Map of global dengue prevalence. Centers for Disease Control and Prevention, USA. Available from: https://www.cdc.gov/dengue/areaswithrisk/around-theworld.html.

17. Malaria - Global Health Observatory data, World Health Organization. Available from: https://www.who.int/gho/malaria/en/.

18. Multiple Sequence Alignment by CLUSTALW. Available from: http://www.genome.jp/tools/clustalw.

19. Kumar S, Stecher G and Tamura K. MEGA7: Molecular Evolutionary Genetics Analysis Version 7.0 for Bigger Datasets. Mol Bio Evol 2016; 33(7): 1870-1874. https://doi.org/10.1093/molbev/msw054

20. Ashok Kumar T. CFSSP: Chou and Fasman Secondary Structure Prediction server. WIDE SPECTRUM: Res Jour 2013; 1(9): 15-19.

21. Buchan DWA and Jones DT. The PSIPRED Protein Analysis Workbench: 20 years on. Nucl Acid Res 2019; 47(W1): W402-W407. https://doi.org/10.1093/nar/gkz297

22. Abbasi WA and Minhas FAA. "ISLAND: In silico prediction of proteins binding affinity using sequence descriptors", DCIS, PIEAS, (preprint release), 2017.

23. Lan J, Ge J, Yu J, Shan S, Zhou H, Fan S, et al. Structure of the SARS-CoV-2 spike receptor binding domain bound to the ACE2 receptor, Nature 2020; (published 30 ${ }^{\text {th }}$ March, 2020). 
https://doi.org/10.1101/2020.02.19.956235

24. Vogt MB, Lahon A, Arya RP, Kneubehl AR, Spencer Clinton JL, Paust S, et al. Mosquito saliva alone has profound effects on the human immune system. PLoS Negl Trop Dis 2018; 12(5): e0006439- e0006465.

https://doi.org/10.1371/journal.pntd.0006439

25. Depinay N, Hacini F, Beghdadi W, Peronet R and Mecheri S. Mast Cell-Dependent Down-Regulation of Antigen-Specific Immune Responses by Mosquito Bites. J Immunol 2006;
176: $4141-4146$

https://doi.org/10.4049/jimmunol.176.7.4141

26. Coronavirus disease 2019 (COVID-19) Situation Report - 49 released on $9^{\text {th }}$ March, 2020, available from: https://www.who.int/ docs/default-source/coronaviruse/situation-reports/20200309sitrep-49-covid-19.pdf?sfvrsn=70dabe61_2.

27. COVID-19 India dashboard, Ministry of Health and Family Welfare, Government of India statistics on April 24, 2020. Available from: https://www.mohfw.gov.in/dashboard/index.php.

\footnotetext{
Authors Contribution:

KB- Conceptualized study, literature search, prepared first draft of manuscript and critical revision of the manuscript, revision of manuscript and review of study; SS- Statistical modeling, writing of methodology and results for statistical modeling, literature search, revision of manuscript and review of study;

EB- Bioinformatic analysis, searching and anlyzing databases, domain domain interactions prediction, literature search, revision of manuscript and review of study; PG- Epidemiological data collection, analysis, table preparation, literature search, revision of manuscript and review of study.
}

\section{Work attributed to:}

Department of Zoology, Ramakrishna Mission Vivekananda Centenary College, Punyananda Sarani, P.O.- Rahara, Khardah, District - 24PGS (N) West Bengal, India. PIN - 700118

\section{Orcid ID:}

Dr. Koutilya Bhattacharjee - (1) https://orcid.org/0000-0002-6752-4840

Source of support: None, Conflicts of Interest: None 


\section{SUPPLEMENTARY TABLE}

Supplementary Table : Genetic variants of SARS-CoV-2 found among different countries. Out of 33 total variations, first 27 were found in the polyprotein encoding ORF1ab gene. Among those 27 variations 6 were reported from USA, 4 from Pakistan, China, Spain and India each. Mutation types were 2 missense, 9 neutral and rest 16 silent in nature. One deletion and five single nucleotide variations were found within the SP1 gene. Among those 5 variations 3 were missense, 1 neutral and 1 silent type of mutation

\begin{tabular}{|c|c|c|c|c|c|c|c|c|c|}
\hline $\begin{array}{l}\text { SI } \\
\text { No. }\end{array}$ & $\begin{array}{c}\text { NCBI } \\
\text { reference } \\
\text { No. }\end{array}$ & $\begin{array}{c}\text { Nucleotide } \\
\text { No. }\end{array}$ & $\begin{array}{l}\text { Change from } \\
\text { (NCBI Id: } \\
\text { NC045512.2) }\end{array}$ & Effective Codon Change & $\begin{array}{c}\text { Amino } \\
\text { Acid } \\
\text { Change }\end{array}$ & & $\begin{array}{l}\text { Amino Acid } \\
\text { No. from } \\
\mathrm{N} \text { terminal }\end{array}$ & $\begin{array}{l}\text { Mutation } \\
\text { Type }\end{array}$ & $\begin{array}{l}\text { Country of } \\
\text { Occurrence }\end{array}$ \\
\hline \multicolumn{10}{|c|}{ Variations found within ORF1ab Gene encoding the poly protein (Nucleotide number 266 - 21555) } \\
\hline 1 & MT240479.1 & 1348 & $\mathrm{C}$ to $\mathrm{T}$ & CCC to CCT & $\mathrm{P}$ to $\mathrm{P}$ & & 361 & Silent & Pakistan \\
\hline 2 & МТ039890.1 & 2971 & G to $T$ & ATG to ATT & M to I & & 902 & Neutral & Republic of Korea \\
\hline 3 & MT135044.1 & 4402 & $\mathrm{~T}$ to $\mathrm{C}$ & CTT to CTC & $\mathrm{L}$ to $\mathrm{L}$ & & 1379 & Silent & China \\
\hline 4 & MT135044.1 & 5062 & $\mathrm{G}$ to $\mathrm{T}$ & TTG to TTT & $L$ to $F$ & & 1599 & Neutral & China \\
\hline 5 & МТ039890.1 & 6031 & $\mathrm{C}$ to $\mathrm{T}$ & AAC to AAT & $\mathrm{N}$ to $\mathrm{N}$ & & 1922 & Silent & Republic of Korea \\
\hline 6 & МТ050493.1 & 6501 & $\mathrm{C}$ to $\mathrm{T}$ & CCA to CTA & $\mathrm{P}$ to $\mathrm{L}$ & & 2079 & Neutral & India \\
\hline 7 & МT012098.1 & 6695 & $\mathrm{C}$ to $\mathrm{T}$ & CCT to TCT & $P$ to $S$ & & 2144 & Missense & India \\
\hline \multirow[t]{10}{*}{8} & МT016054.1 & 8782 & $\mathrm{C}$ to $\mathrm{T} / \mathrm{Y}$ & AGC to AGT/AGC & $S$ to $S$ & & 2839 & Silent & USA \\
\hline & MN988713.1 & 8782 & $\mathrm{C}$ to $\mathrm{T} / \mathrm{Y}$ & AGC to AGT/AGC & $S$ to $S$ & & 2839 & Silent & USA \\
\hline & MT233519.1 & 8782 & $\mathrm{C}$ to $\mathrm{T} / \mathrm{Y}$ & AGC to AGT/AGC & $S$ to $S$ & & 2839 & Silent & Spain \\
\hline & MT233523.1 & 8782 & $\mathrm{C}$ to $\mathrm{T} / \mathrm{Y}$ & AGC to AGT/AGC & $S$ to $S$ & & 2839 & Silent & Spain \\
\hline & MN997409.1 & 8782 & $\mathrm{C}$ to $\mathrm{T} / \mathrm{Y}$ & AGC to AGT/AGC & $S$ to $S$ & & 2839 & Silent & USA \\
\hline & МТ066175.1 & 8782 & $\mathrm{C}$ to $\mathrm{T} / \mathrm{Y}$ & AGC to AGT/AGC & $S$ to $S$ & & 2839 & Silent & Taiwan \\
\hline & MT135044.1 & 8782 & $\mathrm{C}$ to $\mathrm{T} / \mathrm{Y}$ & AGC to AGT/AGC & $S$ to $S$ & & 2839 & Silent & China \\
\hline & MN985325.1 & 8782 & $\mathrm{C}$ to $\mathrm{T} / \mathrm{Y}$ & AGC to AGT/AGC & $S$ to $S$ & & 2839 & Silent & USA \\
\hline & МТ050493.1 & 8782 & $\mathrm{C}$ to $\mathrm{T} / \mathrm{Y}$ & AGC to AGT/AGC & $S$ to $S$ & & 2839 & Silent & India \\
\hline & MN994467.1 & 8782 & $\mathrm{C}$ to $\mathrm{T} / \mathrm{Y}$ & AGC to AGT/AGC & $S$ to $S$ & & 2839 & Silent & USA \\
\hline 9 & MT240479.1 & 9034 & A to $G$ & AAAG to AAG & $\mathrm{K}$ to $\mathrm{K}$ & & 2923 & Silent & Pakistan \\
\hline 10 & MT240479.1 & 9159 & $\mathrm{C}$ to $\mathrm{T}$ & CCT to CTT & $P$ to $L$ & & 2965 & Neutral & Pakistan \\
\hline 11 & МТ093571.1 & 9274 & A to $G$ & AGA to $A G G$ & $\mathrm{R}$ to $\mathrm{R}$ & & 3003 & Silent & Sweden \\
\hline \multirow[t]{2}{*}{12} & MT233519.1 & 9477 & $\mathrm{~T}$ to $\mathrm{A}$ & TTT to TAT & $\mathrm{F}$ to $\mathrm{Y}$ & & 3071 & Missense & Spain \\
\hline & MT233523.1 & 9477 & $\mathrm{~T}$ to $\mathrm{A}$ & TTT to TAT & $\mathrm{F}$ to $\mathrm{Y}$ & & 3071 & Neutral & Spain \\
\hline \multirow[t]{5}{*}{13} & MT126808.1 & 11083 & $G$ to $T$ & TTG to TTT & $\mathrm{L}$ to $\mathrm{F}$ & & 3606 & Neutral & Brazil \\
\hline & MT240479.1 & 11083 & $\mathrm{G}$ to $\mathrm{T}$ & TTG to TTT & $L$ to $F$ & & 3606 & Neutral & Pakistan \\
\hline & LC528232.1 & 11083 & $\mathrm{G}$ to $\mathrm{T}$ & TTG to TTT & $L$ to $F$ & & 3606 & Neutral & Japan \\
\hline & MN997409.1 & 11083 & $\mathrm{G}$ to $\mathrm{T}$ & TTG to TTT & $L$ to $F$ & & 3606 & Neutral & USA \\
\hline & МТ066156.1 & 11083 & $\mathrm{G}$ to $\mathrm{N}$ & TTG to TTT/C or TTG/TTA & $\mathrm{L}$ to $\mathrm{F} / \mathrm{L}$ & & 3606 & Neutral & Italy \\
\hline 14 & МТ093571.1 & 13225 & $\mathrm{C}$ to $\mathrm{G}$ & TCC to TCG & $S$ to $S$ & & 4320 & Silent & Sweden \\
\hline \multirow[t]{3}{*}{17} & MT233519.1 & 14805 & $\mathrm{C}$ to $\mathrm{T}$ & TAC to TAT & $Y$ to $Y$ & & 4847 & Neutral & Spain \\
\hline & MT233523.1 & 14805 & $\mathrm{C}$ to $\mathrm{T}$ & TAC to TAT & $Y$ to $Y$ & & 4847 & Neutral & Spain \\
\hline & MT126808.1 & 14805 & $\mathrm{C}$ to $\mathrm{T}$ & TAC to TAT & $Y$ to $Y$ & & 4847 & Neutral & Brazil \\
\hline 18 & МТ039890.1 & 15597 & $\mathrm{~T}$ to $\mathrm{C}$ & TAT to TAC & $Y$ to $Y$ & & 5111 & Silent & Republic of Korea \\
\hline 19 & МТ050493.1 & 16877 & $\mathrm{C}$ to $\mathrm{T}$ & ACA to ATA & T to I & & 5538 & Missense & India \\
\hline 20 & MT126808.1 & 17247 & $\mathrm{~T}$ to $\mathrm{C}$ & CGT to CGC & $\mathrm{R}$ to $\mathrm{R}$ & & 5661 & Silent & Brazil \\
\hline 21 & МT012098.1 & 17373 & $\mathrm{C}$ to $\mathrm{T}$ & GCC to GCT & $A$ to $A$ & & 5703 & Silent & India \\
\hline 22 & МТ093571.1 & 17376 & A to $G$ & ACA to ACG & $\mathrm{T}$ to $\mathrm{T}$ & & 5704 & Silent & Sweden \\
\hline 23 & MN985325.1 & 18060 & $\mathrm{C}$ to $\mathrm{T}$ & CTC to CTT & $\mathrm{L}$ to $\mathrm{L}$ & & 5932 & Silent & USA \\
\hline 24 & MT106054.1 & 18603 & $\mathrm{~T}$ to $\mathrm{C}$ & CAT to CAC & $\mathrm{H}$ to $\mathrm{H}$ & & 6113 & Silent & USA \\
\hline 25 & MT106054.1 & 18975 & $\mathrm{~T}$ to $\mathrm{A}$ & GTT to GTA & $\mathrm{V}$ to $\mathrm{V}$ & & 6237 & Silent & USA \\
\hline 26 & МТ007544.1 & 19065 & $\mathrm{~T}$ to $\mathrm{C}$ & CCT to CCC & $\mathrm{P}$ to $\mathrm{P}$ & & 6267 & Silent & Australia \\
\hline 27 & MT106054.1 & 19175 & A to $\mathrm{C}$ & GAT to GCT & $D$ to $A$ & & 6304 & Missense & USA \\
\hline \multicolumn{10}{|c|}{ Variations found within SP1 Gene encoding the spike glycoprotein (Nucleotide No. 21563 - 25384) } \\
\hline 1 & MT012098.1 & 21991 & $\triangle \mathrm{TTA}$ & --- & --- & 143 & Deletion & & India \\
\hline 2 & МТ039890.1 & 22224 & $\mathrm{C}$ to $\mathrm{G}$ & TCG to TGG & $\mathrm{S}$ to $\mathrm{W}$ & 221 & Missense & & Republic of Korea \\
\hline 3 & МT012098.1 & 22785 & $\mathrm{G}$ to $\mathrm{T}$ & AGA to ATA & $\mathrm{R}$ to I & 408 & Missense & & India \\
\hline 4 & МТ093571.1 & 23952 & $\mathrm{~T}$ to $\mathrm{G}$ & TTT to TGT & $\mathrm{F}$ to $\mathrm{C}$ & 797 & Missense & & Sweden \\
\hline \multirow[t]{3}{*}{5} & МT072688.1 & 24034 & $\mathrm{C}$ to $\mathrm{T}$ & AAC to AAT & $\mathrm{N}$ to $\mathrm{N}$ & 824 & Silent & & Nepal \\
\hline & MN994467.1 & 24034 & $\mathrm{C}$ to $\mathrm{T}$ & AAC to AAT & $\mathrm{N}$ to $\mathrm{N}$ & 824 & Silent & & USA \\
\hline & MN988713.1 & 24034 & $\mathrm{C}$ to $\mathrm{Y}$ & AAC to AAT/AAC & $\mathrm{N}$ to $\mathrm{N}$ & 824 & Silent & & USA \\
\hline 6 & МТ050493.1 & 24351 & $\mathrm{C}$ to $\mathrm{T}$ & GCT to GTT & A to $V$ & 930 & Neutral & & India \\
\hline
\end{tabular}

